\title{
Contemporary Conflict Resolution and Islamic Conflict Resolution: Similarity and Differentiation on the Theoretical Level
}

\author{
Nabilla Sabban \\ President University \\ Jababeka, Cikarang, 17550 \\ nabillasabban@yahoo.com
}

\begin{abstract}
The critiques towards Cosmopolitan conflict resolution theory that it cannot be applied universally because it is incompatible with the characteristics of the conflict in the other part of the world beyond Western significantly influence the field. Several scholars argue that the theory specifically cannot help to solve the current conflicts that generally happen in the Islamic Worlds or Countries or involved Islamic fundamentalist group because it was taken from the culture, the norms and the values of Christian Western Europe and North America experiences. Thus, this rise a question, do we need to have new perspective or theory of Conflict Resolution to solve particular conflicts in the Islamic World or Countries such as from the Islamic perspective? However, it is not easy since Islam particularly after $9 / 11$ is commonly identified as religion and culture that inherently violent. Stand from this point of view the author want to explore on the essay whether the Cosmopolitan Conflict Resolution seriously cannot be applied universally especially in the Islamic World and pop up with the possibility of Conflict Resolution theory from the Islamic perspective.

Keywords: Conflict Resolution, Islam, Negotiation, Reconciliation, Arbitration
\end{abstract}

\begin{abstract}
Abstrak
Kritik terhadap teori resolusi konflik Kosmopolitan adalah bahwa teori itu tidak dapat diterapkan secara universal, karena tidak sesuai dengan karakteristik konflik di luar dunia Barat. Beberapa ahli berpendapat bahwa teori ini tidak dapat membantu memecahkan konflik yang umumnya terjadi di Dunia Islam atau negara atau kelompok fundamentalis Islam karena diambil dari budaya, norma-norma dan nilai-nilai Kristen Eropa Barat dan pengalaman Amerika Utara. Hal ini menimbulkan pertanyaan, apakah kita memerlukan perspektif atau teori Resolusi Konflik baru untuk menyelesaikan konflik tertentu di Dunia atau Negara Islam - seperti dari perspektif Islam? Namun, hal ini tidak akan mudah karena Islam, terutama setelah tragedi 9/11, diidentifikasi sebagai agama dan budaya yang dekat dengan kekerasan. Melalui sudut pandang ini, penulis ingin mengkaji apakah Penyelesaian Konflik Kosmopolitan benar-benar tidak dapat diterapkan secara universal, terutama di dunia Islam dan memunculkan kemungkinan teori Penyelesaian Konflik dari perspektif Islam.

Kata Kunci: Resolusi Konflik, Islam, Negosiasi, Rekonsiliasi, Arbitrasi
\end{abstract}

\section{INTRODUCTION}

Civil wars that exist in several Islamic countries such as Syria, Lebanon, Egypt, Palestine, Libya and Iraq or wars that involve Islamic groups or Islamic fundamentalist organization in Myanmar, the Philippines, Afghanistan and Pakistan are now seen as new sources of human misery and global insecurity after the end of the II World War. These conflicts occurred at the local context with the global impact that can be felt universally (Ramsbotham et al, 2011). Many efforts have been done by the international world to solve those conflicts such as peace talk initiate by several western countries like US, Italy and France in dealing with the Syrian conflict, or several peace agreements 
made since 1967 that also involve western countries as third party to solve the Israel - Palestine conflict (BBC, 2013). Unfortunately, peace is not easily created and achieved after those interventions; and conflictsstill exist and even killed more and more people. Critics then come up; could the contemporary conflict resolution theory be applied universally in particular through the Islamic world?

Some scholars argues that the contemporary conflict resolution theory and practice that used universally by the international institution such as the United Nation is coming from the norms, cultures and experience of the Christianity and Western countries in the North America and Western Europe in dealing with their conflicts during the World Wars era (Nimer, 2010). Thus, it cannot be applied easily in the non-Western world since there are different cultures and characters of the conflicts. Hence, there is a need to review the existing theory and the possibility of hybrid itwith the theory and practice of conflict resolution from different perspectives such as Islamic (Nimer, 2010). However, since the incident of 9/11 in which a group of terrorists claim their inhuman and immoral action on behalf of Islam, many people identified Islam as a religion of the terrorist that inherently violent and far from peace. As the result, people questioning is Islam a peaceful religion? And is there any conflict resolution initiation within Islam? Due to this situation Islam suddenly become the center of the attention, many Western scholars and practitioners do researchabout Islam from all aspect of livesespecially peace. Everything with the Islamic labelis sold out on the marketbecause it is considered as new threat to the global security therefore people need to be aware of it. It seems like the Western World wants to tame Islam. Islamic conflict resolution then emerges as if it is a solution to solve all the existing conflict that we have discussed above. However, is it true that the Islamic conflict resolution can handle all these conflicts compare to the contemporary conflict resolution? What are the similarity and differentiation between both of the theories?

In regard to answer those questions above this paper will try to focus merely on the theoretical level of both of the theories. Consequently, the first part of the paper will discuss about the contemporary conflict resolution and the Islamic conflict resolution theories. The second part will unveil two of the main processes of conflict resolution in both contemporary and Islamic perspectives (reconciliation and mediation). Last but not least, the conclusion of this paper state that Islam also taught its followers to spread peace on earth and initiate peaceful settlement as what the contemporary conflict resolution theory did. However, the things that differentiate both of the concepts lie on three factors which are the basic assumption, process and level, and the role of the third party.

\section{THE CONTEMPORARY CONFLICT RESOLU- TION AND THE ISLAMIC CONFLICT RESOLU- TION THEORY}

Conflict resolution as a new field of study was born in the 1950s and 1960 when conflict between superpowers countries were seen could threaten the existing of human lives during the Second World War and the Cold War (Ramsbotham et al, 2011). Scholars from different disciplines then thought that they need to have mechanism that could be used to end the conflicts and make a better world for all of the human being. They believed that conflict is a general phenomenon that exists not merely in the international relation arena but also in the domestic politics, industries, communities, families and even the individuals. Thus, there is a potential to develop an approach that could handle particular conflict in the industrial relation to the conflict ingeneral such as local and international conflict (Ramsbotham et al, 2011). However, this idea to create a peaceful and a better world did not work easily. There are many phases and process need to be passed by those peace activists before the concept was accepted by the international community and implemented to solve certain conflicts such as what happened in the Northern Ireland and South Africa (Ramsbotham et al, 2011) 
Furthermore, by the end of the Cold War,thepattern of the world's conflict changed significantly. The relation between superpower countries were getting better and Soviet Union fell down into pieces. The numbers of wars or conflicts between states then decrease notablymeanwhile the conflicts within a state such as ethnic, religious, race and power domination increase dramatically (Ramsbotham et al, 2011). This dramatic change of conflict types attract so much international relation and comparative politics scholars to come back to the exact types of conflict that had been dominated conflict resolution thinkers for so many times (Ramsbotham et al, 2011). As the result, conflict resolution as new field of study grow fastly and attract more and more scholars, students and practitioners to focus on it (Nimer, 2010).Nonetheless, in the 1990s when the theories and practices of conflict resolution were dominated by Western approach, some scholars and practitioner started to examine the applicability of the concepts and skills in the non-white and the non-Anglo SaxonAmerican context to find out the significant of culture(Nimer, 2010, p.73). Ergo, they found out that the practitioners (mediator, facilitator, and negotiator) need to address cultural differences more seriously in the Middle East or other non-Western cultural context in the conflict resolution and peacemaking process (Nimer, 2010, p. 73). However, Burton counter this argument by saying that cultural differences are not significant at all in the conflict resolution and peacemaking process; but on the other hand Zartman published significant piece of working about the important of culture in the African models of conflict resolution in resolving their conflict (Nimer, 2010, p.73). The debate and the critics towards the contemporary conflict resolution did not stop at that point, the other international world conflicts phenomenon enhance the number of the critics, such as followed. First is in regard to the conflict settlement in chaotic war zones and the distribution of cheap weaponry. Bosnia (1992-5) and Somalia (1992-3) are the examples in which the international interveners unable to do their job. Hence, this failure also led to the weakening of the state control over weapon distribution that increases the asymmetric war within the state. Second is the outbreak of the second intifada between Israel and Palestine as a sign of the breakdown of Oslo peace agreement between both countries in September 2000. If Oslo peace agreement succeeded to bring peace in Palestine - Israel conflict, it would be used as a parameter of the success of classic conflict resolution process; unfortunately it did not work as smooth as the plan. Third is the terrorist attack to the World Trade Center buildingon September 11, 2001 and followed by the Global War on Terror policy.Both of the events then made global Jihadist becomes a new problem face by the international world (Ramsbotham, et al, 2011).

Consequently, those three critics above threaten the credibility of the contemporary conflict resolution theory, in particular related to the ability of it in solving conflicts that exist in the non-western or Islamic country such as several cases mentioned above (Ramsbotham et al, 2011). Due to this situation, some Muslim and non-Muslim scholars tried to over different perspective of conflict resolution which coming from the Islamic cultures and beliefs. They argued there is a need to develop non-western approach to peace and conflict resolution not merely because it is important but also to promote cross culture and multi religious of peace (Said et al, 2001, p. 3). Besides, the ongoing conflict of today's world mostly happen in the Islamic worlds or at least involve Islamic fundamentalist group thus the need to use Islamic perspective to resolve those conflict is even higher (Nimer, 2010).

Abdul Ghafar Khanthen argue "by using the Islamic values of service (amal), faith (yakeen), and love (mohabat) the connection between Islam and peace building is more obvious and stronger than the religion's stereotypical link to violence" (Nimer, 2010). Hetried to unveil some Islamic values that contain peaceful messages and principles that repeatedly mentioned in the Qur'an and the Prophet's tradition such as social justice, brotherhood, equality of mankind (elimination of racial discrimination and slavery), 
tolerance, submission to God, and the acknowledgement of human rights to emphasize peaceful messages of Islam (Nimer, 2010, p. 77). Moreover, other scholars try to expose the other Islamic values that have direct relation to peace building and development like justice (adl), benevolence (ihsan), compassion (rahmah), and wisdom (hikmah)in order to strengthen their argument of the need to consider Islamic perspective in conflict resolution (Nimer, 2010, p.77).The way Muslim and Western people perceive peace and conflict is totally different. Western world see conflict as something natural. Even though conflict could bring destructive impact such as human misery and instability but it could also give positive impact. On the other hand, Muslims see it in the other way around. Peace in the West is always associated with the absent of war and violation against human rights. It is institutionalized and regulated by some decision making procedures. Meanwhile, Muslim identifies peace with God; "God is peace, for peace (al-salam) is one of the "most beautiful names" of God" (Said et al, 2001, p. 3).

From all these explanations above about the contemporary conflict resolution and Islamic conflict resolution, Abu Nimer (1996) as one of the scholars in the field believe that in order to find out the differentiation between both of the concepts and to prove whether the contemporary conflict resolution could not be applied universally in particular through the Islamic world; we need to go to the main process of conflict resolution which are "reconciliation, facilitation, negotiation, mediation and arbitration". Nonetheless, the following part of the paper will merely focus on the two main process of conflict resolution from both western and Islamic perspectives, which are reconciliation and mediation hence to find out the similarity and differentiation of both skill and concepts.

\section{MAIN PROCESSES OF CONFLICT RESOLU- TION (RECONCILIATIONANDMEDIATION)IN THE CONTEMPORARY AND THE ISLAMIC PERSPECTIVES}

Based on western perspectives, "conflict is a universal feature of human society. It takes its origin in economic differentiation, social change, cultural formation, psychological development and political organization - all of which are inherently conflictual and becomes overt through the formation of conflict parties which come to have or are perceived to have, mutually incompatible goals" (Ramsbotham et al, 2011, p.7). Conflictis inevitable in international relation and expensive in terms of human lives and materialsif it contains violent (Jeong, 2011). Consider this cost of war, scholars and practitioners prefer to use peaceful mechanism in handling conflict. However, it is not easy because it needs strong commitment from all parties. Even though it is hard, the awareness about the consequences of conflict make people initiate various types of peaceful settlement and even institutionalized conflict management process. In the chapter VI of the UN charter for instance, we can find instruction about peaceful settlement of a dispute with the use of several methods such as "negotiation, enquiry, mediation, conciliation, arbitration, and judicial settlement (Jeong, 2011).

Reconciliation in the western perspective is considered as the core of conflict resolution in which it is able to restore the broken relationship and help people to live non-violently (Ramsbotham et al, 2011). According to (Jeong, 2011) "reconciliation contributes to the restoration of humanity of both sides by establishing just relationship. Because reconciliation is a mutual process, acknowledgment of guilt and forgiveness are essential to the integrity of the relationship. Re-establishing the political and social relationship of the two sides is made possible by a transaction between contrition and forgiveness". Besides, John Paul Lederach who produced many works about reconciliation state reconciliation is a mechanism in which both of the conflicting parties able to engage as human beings. In the reconciliation process all the conflicting parties can meet to share their painful experiences, fears, and hopes for a better future (Lederach, 1997).Usually, at the beginning of reconciliation process both of the conflicting parties find it 
is hard for them to meetand talk about their pain and fear since there is psychological influence of violent attack and loss of loved ones by warfare. However, reconciliation is needed to heal all this psychological traumatism. Lederach presuppose reconciliation as a meeting place or locus that inspired by Psalm 85 in the Bible "reconciliation is both a journey we must take and a place we are trying to reach" (Lederach, 1997, p.28). Reconciliation is not merely important to restore present relation but also affect the relationship of the next generation (Lederach, 1997).

In Islam, reconciliation is known as Sulh and it is suggested in the Qur'an as one of the mechanisms to resolve a conflict (Fadl, 2003, p.179). "Sulh is a part of every conflict resolution in Islam because it is considered as a legal instrument made not merely to aim to solve the private conflict among individuals but also among groups in lieu of litigation" (Fadl, 2003, p.179). Two of the Qur'an verses that recommend Sulh or reconciliation are Qur'an verse 128, Sura Nisa("Reconciliation between them and reconciliation (peace) is better") and Qur'an verses 9 in Sura Al-Hujarat ("If two parties among the Believers fall into a quarrel, make ye peace between them... make peace between them with justice, and be fair: For God loves those who are fair and just"). However, the second verses above emerge critical question such as how about peace between the believers and the non-believers? Is it still relevance or not? But this issue will not be discussed in this paper. Sulh is commonly practice to resolve inter and intra communal dispute in the Middle East and many other Muslim countries in Asia and Africa. The practice of Sulh in Muslim worlds is combined with the local culture. For instance in Israel, Sulh does not include to the formal legal system but it has significant role in maintaining peace and resolve conflict within the Israel Arab community (Pely, 2010).

Further, mediation in the western perspective is defined as "a process in which parties to a dispute attempt to reach a mutually agreeable solution under the auspices of a third party" (Hoffman, 1992, p.265 in Jeong, 2011). Third party has significant role in mediation process since it can help to minimize the adversarial relationship. Mediation gives space for the conflicting parties to solve their own conflict however it also allows third party to interfere the negotiation process. Third party in the western or contemporary conflict resolution should uphold several principles of mediation such as confidential, impartial, and neutral. On the other hand, in the Islamic tradition, mediation is also acknowledged as one of conflict resolution mechanisms besides reconciliation (sulh) and arbitration (tahkim).Mediation has existed in the Islamic tradition even before there is law in the Qur'an that stated about it. Prophet Muhammad is one of the great mediatorsin the history of Islamic tradition. He was trusted by the people in Medina (Yathrib) as a third party in mediating the conflict between tribes in that city (Yildirim, 2006). In this context, (Merry in Yildirim 2006) argues "in mediation, the mediator is able to exert influence and social pressure to persuade an intransigent party to accept some settlement... (deriving) their authority to intervene from their positions in kinship networks, their wealth, their political power, their religious merit, and their past successes at mediation". In addition, besides the previous explanation there are four reasons conclude by Hamidullah (in Yildirim, 2006) about the success of Prophet Muhammad as a third party in the conflict dispute among tribes in Medina as followed. First, there was a vacuum of leadership power in the area, which gave opportunity for the Prophet to take the chance. Second, at that time, it was common for the Arab people to trust foreigner in their dispute resolution and Muhammad had a good reputation as trustworthy mediator in solving the conflict in Mecca. Third, there was a lack alignment in religious lines before his coming to the city thus he is able to use religious sanction in influencing tribal leaders. And fourth, Prophet Muhammad is also drafting the Medina charter during that process, and in doing so he discussed and negotiated with the leaders of each tribeabout their willingness and needs. So once the tribal leaders accept the charter the younger members of the tribes will also accept that regardless of religion (Yildirim, 2006). Hence, mediation in Islamic tradi- 
tion is not something new since the Prophet already used it as an example in solving the tribal conflict of primordial Arab societies.

Is Islam a peaceful religion? The answer towards this question might be a little bit answered by the explanations above that Islam also taught its followers to spread peace and suggest peaceful disputes settlement such as mediation, reconciliation, and arbitration in resolving conflict. However, what are exactly the things that differentiate Islamic perspective in conflict resolution with the contemporary conflict resolution? To find out the answer, we can start from the work of Abu Nimer (1996) and George Irani and Nathan Funk (2000) in MacQueen (2004), those scholars argue that there are three things that differentiate Islamic notion of conflict resolution which are "basic assumptions", processes and levels", and "third party roles".

The basic assumptions that differentiate contemporary or western model of conflict resolution and the Arab-Islamic conflict resolution is laid in the interpretation of particular culture in the process of conflict and resolution (MacQueen, 2004). The dispute resolution in the western perspective which dominantly influence by liberalism and rational-choice theory perceived individual as primary focus. Meanwhile, in the Arab-Islamic tradition of conflict resolution sees the important of community in the resolution process and the effort to maintain the status quo. Western perceived conflict as something that happen within individuals and individual hence it needs to merely focus on this level. "This differs markedly from the Arab-Islamic conception that focuses on the importance of community cohesion, with individual rights often subsumed by the perceived interests of the greater community” (MacQueen, 2004). Moreover, in the process and levels; there are some specific mechanisms and methods that differentiate both Western and Islamic-Arab conflict resolution. In the Islamic tradition of conflict resolution arbitration (tahkim), reconciliation (sulh), mediation, and consulation (shurah) are acknowledged and even practiced by the Prophet Muhammad. However, Islamic tradition does not institutionalize them and merely apply those peaceful settlements when the traditional norms legitimize those actions. And this that makes it differs from the western way of conflict resolution. Last but not least is about the role of the third party. In the western or contemporary conflict resolution mechanism, third party is acted as "facilitator" a neutral person who advocates the resolution and has no interest at the result of the resolution process. While, in the Islamic-Arab model, the role of the third party is more like "adjudicator" in which he/she could enforce settlement of the dispute and has sufficient knowledge about the conflict and has interest towards the outcome of conflict resolution (MacQueen, 2004).According to Abu Nimer, the Islamic-Arab societies cannot accept the model of conflict resolution in which the third party acted as "facilitator" because it will always be identified as western intervention in their conflict. Thus it doesn't work very well in the Middle Easter conflict context (MacQueen, 2004).

\section{CONCLUSION}

There are some points drawn as the conclusions of this study about the similarity and differentiation of the contemporary conflict resolution and the Islamic conflict resolution. First is the prejudice about Islam as the religion that inherently violence is indisputable since Islam also taught its followers to create peace and prioritize peaceful settlement compare to violent mechanism in dealing with conflict. Second, both contemporary and Islamic conflict resolution imply main processes of conflict resolution (mediation, reconciliation, arbitration, and etc.) in the conflict resolution process. Third, culture play significant role in the process of conflict resolution. Western culture and Arab-Islamic culture is totally different especially in the way they resolve a dispute thus the practitioners and scholars need to be careful in this issue. Last but not least, this paper acknowledges that even though both perspectives have some differentiations but they also have several similarities; both aim to create peace and a better world for everyone who lives within it. 


\section{REFERENCES:}

CHANDLER, D. 2007. The responsibility to protect? Imposing the "liberal peace".International peacekeeping [Online].11:1 (59-81). Available at: http://dx.doi.org/10.1080/1353331042000228454 [Accessed: 12th July 2013].

FADL, K. A. E. (2003). Conflict Resolution as a Normative Value in Islamic Law. In: JOHNSTON, D. (2003). Faith-based diplomacy: trumping realpolitik. New York: Oxford University Press.

JEONG, H.-W. (2000). Peace and conflict studies : an introduction. Aldershot: Ashgate.

JOHNSTON, D. (2003). Faith-based diplomacy : trumping realpolitik. New York: Oxford University Press.

LEDERACH, J. P. (1999) The journey toward reconciliation. Scottdale, Pa.: Herald Press.

LEDERACH, J. P. (2003) The little book of conflict transformation. (The little books of justice and peacebuilding) Intercourse, PA: Good Books.

LEDERACH, J. P. (2005) The moral imagination : the art and soul of building peace. Oxford: Oxford University Press.

MACQUEEN, B. 2004.Civil war, Islamic Politics and Conflict Resolution in the Arab Islamic World. $15^{\text {th }}$ Biennial Conference of the Asian Studies Association of Australia. Available at: http:// coombs.anu.edu.au/SpecialProj/ASAA/biennial-conference/2004/ MacQueen-B-ASAA2004.pdf [Accessed: 02 November 2013].

NEWMAN, E and PARIS, R and RICHMOND, O.P. New perspectives on liberal peacebuilding. Japan: United Nation University Press, 2009.

NIMER, M. A. (2003) Nonviolence and peace building in Islam : theory and practice. Gainesville, Fla.London: University Press of Florida ;Eurospan.

NIMER, M. A. (2001). An Islamic Model of Conflict Resolution: Principle and Challenges. In: HUDA, Q.-U. and UNITED STATES INSTITUTE OF PEACE. (2010) Crescent and dove : peace and conflict resolution in Islam. Washington, D.C.: United States Institute of Peace Press.

PELY, D. 2010. Honor: The Sulha's Main Dispute Resolution Tool. Conflict Resolution Quarterly [Online]. 28:1 (67-81). Available at: http://papers.ssrn.com/sol3/papers.cfm?abstract_id =2263789 [Accessed: 01 November 2013].

RAMSBOTHAM, O., et al. (2011).Contemporary conflict resolution : the prevention, management and transformation of deadly conflicts. Oxford: Polity.

RICHMOND, O. P. (2007). The Transformation of Peace. Houndmills, Basingstoke, Hampshire and New York: Palgrave Macmilan

SAID, A. A., et al. (2001).Peace and conflict resolution in Islam. Precept and practice. Maryland: University Press of America.

YILDIRIM, Y. 2006. Peace and Conflict Resolution in the Medina Charter. Peace Review: A Journal of Social Justice [Online]. 18:1 (109-117). Available at: http://www.tandfonline.com/doi/abs/ 10.1080/10402650500510750?journalCode=cper20\#preview [Accessed: 02 November 2013]. 